\title{
PENGARUH CAPITAL ADEQUACY RATIO, DANA PIHAK KETIGA, FINANCING TO DEPOSIT RATIO, DAN NON PERFORMING FINANCING \\ TERHADAP PEMBIAYAAN MURABAHAH \\ (Pada Bank Umum Syariah Periode 2013 - 2018)
}

\author{
Hesty Erviani Zulaecha ${ }^{(1)}$ \\ Universitas Muhammadiyah Tangerang \\ hesty_erviani@yahoo.com \\ Firlia Yulistiana ${ }^{(2)}$ \\ Universitas Muhammadiyah Tangerang \\ Yfirlia14@gmail.com
}

\begin{abstract}
ABSTRAK
Tujuan dari penelitian ini untuk mengetahui dan menjelaskan seberapa besar pengaruh Capital Adequacy Ratio, Dana Pihak Ketiga, Financing to Deposit Ratio, dan Non Performing Financing terhadap Pembiayaan Murabahah pada Bank Umum Syariah Periode 2013 - 2018.

Populasi penelitian ini adalah Bank Umum Syariah yang terdaftar di Bank Indonesia sebanyak 14 bank periode 2013 - 2018. Teknik pengambilan sampel menggunakan teknik purposive sampling. Berdasarkan kriteria yang telah ditetapkan diperoleh 9 Bank Umum Syariah. Jenis data yang digunakan adalah data sekunder yang diperoleh dari situs resmi masing - masing Bank Umum Syariah. Metode analisis yang digunakan adalah analisis regresi data panel.

Hasil penelitian menunjukkan bahwa Capital Adequacy Ratio, Financing to Deposit Ratio, dan Non Performing Financing tidak berpengaruh terhadap Pembiayaan Murabahah, Dana Pihak Ketiga berpengaruh terhadap Pembiayaan Murabahah. dan Capital Adequacy Ratio, Dana Pihak Ketiga, Financing to Deposit Ratio, dan Non Performing Financing secara bersama-sama berpengaruh terhadap Pembiayaan Murabahah.
\end{abstract}

Kata Kunci : Pembiayaan Murabahah, Capital Adequacy Ratio, Financing to Deposit Ratio, dan Non Performing Financing

\section{PENDAHULUAN}

Saat ini pembiayaan bermasalah sudah sangat tidak asing lagi untuk di perbincangkan akibat seringnya kasus seperti ini terjadi. Tidak di ragukan lagi kalau sampai saat ini di dalam dunia perbankan syariah tidak terlepas dari masalah itu (Nadya, 2018). Besarnya Non Performing Financing pada Desember 2018 mencapai 3, 26\% menjadi dampak besarnya alokasi yang disediakan oleh bank untuk pembiayaan tanpa dibarengi manajemen risiko yang baik di hampir seluruh provinsi di Indonesia. 
Besarnya pembiayaan, memperbesar risiko terhadap kualitas pembiayaan pada bank terutama di bank syariah. Hal ini menjadi peringatan bagi perbankan syariah, agar adanya perbaikan dalam pembiayaan. Terutama dalam hal jual beli (murabahah). Salah satu produk perbankan syariah dalam pembiayaan murabahah adalah dengan adanya pembelian Kepemilikan Rumah. Cicilan dalam Kepemilikan Rumah yang tersendat akan mempengaruhi naiknya NPF (Nadya, 2018). Pembiayaan murabahah merupakan menjual barang dengan harga jual sebesar biaya perolehan ditambah keuntungan yang disepakati dan penjual harus mengungkapkan biaya perolehan barang tersebut kepada pembeli.

CAR menjadi rasio yang menunjukkan kemampuan bank dalam menutup penurunan aktiva sebagai akibat dari kerugian kerugian bank yang disebabkan oleh aktiva yang beresiko. Dana Pihak Ketiga atau simpanan dana yang dipercayakan oleh masyarakat kepada bank berdasarkan perjanjian penyimpanan dana dalam bentuk giro, tabungan, deposito dan atau bentuk lainnya (Bank Indonesia, 1998). Financing to Deposit Ratio ditentukan oleh perbandingan antara jumlah kredit atau pembiayaan yang diberikan oleh bank dengan dana yang diterima oleh bank. Non Performing Financing termasuk dalam faktor yang mempengaruhi pembiayaan. Rasio ini berkaitan dengan pembiayaan - pembiayaan bermasalah dan total pembiayaan yang disalurkan oleh bank syariah.

\section{TINJAUAN PUSTAKA}

\section{Bank Syariah}

Bank syariah adalah bank yang dalam kegiatannya memberikan jasa dalam lalu lintas pembayaran. Menurut Undang Undang Nomor 21 tahun 2008 Pasal 4 dan Pasal 3 Perbankan Syariah menyebutkan bahwa tujuan dari perbankan syariah adalah menunjang pelaksanaan pembangunan nasional dalam rangka meningkatkan keadilan, kebersamaan dan pemerataan kesejahteraan rakyat.

\section{Pembiayaan Murabahah}

Murabahah adalah akad jual beli barang dengan menyatakan harga perolehan dan keuntungan yang disepakati oleh penjual dan pembeli (Aziza \& Mulazid, 2017). Pembayaran murabahah dapat dilakukan secara tunai atau cicilan. Dalam murabahah juga diperkenalkan adanya perbedaan dalam barang untuk cara pembayaran yang berbeda. Murabahah muajjal dicirikan dengan adanya penyerahan barang di awal akad dan pembayaran kemudian (setelah awal akad), baik dalam bentuk angsuran maupun dalam bentuk lump sum (sekaligus). Rukun murabahah terdiri dari penjual, pembeli, barang, harga jual, ijab qabul.

\section{Capital Adequacy Ratio}

Capital Adequacy
Ratio
merupakan rasio
memperlihatkan seberapa jauh
seluruh aktiva bank yang
mengandung risiko (kredit,
penyertaan, surat berharga,
tagihan pada bank lain) ikut
dibiayai dari dana modal sendiri
(Aziza \& Mulazid, 2017).


Semakin besar nilai CAR mencerminkan kemampuan perbankan yang semakin baik dalam menghadapi kemungkinan risiko kerugian. CAR dapat diperoleh dengan membagi total modal dengan asset tertimbang menurut risiko (ATMR).

Aktiva Tertimbang Menurut Risiko (ATMR) adalah nilai total masing- masing aktiva bank setelah dikalikan dengan masingmasing bobot risiko aktiva tersebut (Nurbaya, 2013).

\section{Dana Pihak Ketiga}

Dana Pihak Ketiga (DPK) merupakan dana yang dipercayakan masyarakat (di luar bank) kepada bank berdasarkan perjanjian penyimpanan dana (Rinaldy, 2008; Nurbaya, 2013). Sumber-sumber penghimpunan dana (tidak termasuk modal) perbankan syariah secara umum didominasi oleh Dana Pihak Ketiga (Aziza \& Mulazid, 2017). Pos-pos ini terdiri dari simpanan dalam bentuk giro, deposito, dan tabungan.

\section{Financing to Deposit Ratio}

Financing to Deposit Ratio (FDR) merupakan rasio yang digunakan untuk mengukur likuiditas suatu bank dalam membayar kembali penarikan dana yang dilakukan deposan dengan mengandalkan pembiayaan yang diberikan sebagai sumber likuiditasnya, yaitu dengan cara membagi pembiayaan yang diberikan oleh bank terhadap Dana Pihak Ketiga. Menurut Yulihapsari et al. (2017) standar yang digunakan Bank Indonesia untuk rasio FDR adalah $80 \%$ hingga $110 \%$.

\section{Non Performing Financing}

Menurut Bank Indonesia Non Performing Financing adalah suatu rasio yang membandingkan tingkat pembiayaan bermasalah (pembiayaan yang dikualifikasikan) terhadap total pembiayaan yang diberikan. Sedangkan menurut Aziza \& Mulazid (2017) Non Performing Financing (NPF) adalah rasio antara pembiayaan yang bermasalah dengan total pembiayaan yang disalurkan oleh bank syariah. Berdasarkan kriteria yang sudah ditetapkan oleh Bank Indonesia kategori yang termasuk dalam NPF adalah pembiayaan kurang lancar, diragukan dan macet.

\section{Hipotesis}

a. Pengaruh capital adequacy ratio terhadap pembiayaan murabahah

Secara esensial CAR
menetapkan bahwa terhadap
pos-pos tertentu, terutama
aktiva tidak produktif dan
aktiva produktif yang
kualitasnya "memburuk" harus
dibiayai dengan dana sendiri
(Nurbaya, 2013).
Semakin besar CAR maka
akan semakin banyak pula
dana yang dapat disalurkan
melalui pembiayaan
murabahah. Penelitian ini telah
dilakukan oleh Nurbaya (2013)
yang menyatakan bahwa CAR
berpengaruh positif terhadap
pembiayaan murabahah.
H. Capital Adequacy Ratio
berpengaruh positif terhadap
Pembiayaan Murabahah.




\section{b. Pengaruh dana pihak ketiga terhadap pembiayaan murabahah}

DPK merupakan sumber likuiditas untuk memperlancar pembiayaan yang terdapat pada sisi aset neraca bank. Sehingga semakin banyak DPK yang berhasil dihimpun, maka akan semakin banyak pula pembiayaan murabahah yang dapat disalurkan oleh bank tersebut. Teori ini sesuai dengan penelitian yang dilakukan Ali \& Miftahurrohman (2016) yang menyatakan bahwa DPK berpengaruh positif terhadap pembiayaan murabahah.

$\mathrm{H}_{2}$ : Dana Pihak Ketiga berpengaruh positif terhadap Pembiayaan Murabahah.

\section{c. Pengaruh financing to deposit ratio terhadap pembiayaan murabahah}

Financing to Deposit Ratio (FDR) merupakan merupakan rasio yang digunakan untuk mengukur likuiditas suatu bank dalam membayar kembali penarikan dana yang dilakukan oleh deposan dengan mengandalkan pembiayaan yang diberikan sebagai sumber likuiditasnya (Anggara, 2017). Dengan demikian semakin tinggi FDR dalam pembiayaan untuk keperluan kredit termasuk pembiayaan murabahah juga akan meningkat. Penelitian ini didukung oleh Lestari (2014) yang menyatakan bahwa FDR berpengaruh positif terhadap pembiayaan murabahah.

$\mathrm{H}_{3}$ : Financing to Deposit Ratio berpengaruh positif terhadap Pembiayaan murabahah.

d. Pengaruh non performing financing terhadap pembiayaan murabahah

Non Performing Financing merupakan indikator yang digunakan untuk menunjukkan kerugian akibat resiko pembiayaan (Lifstin \& Kusumaningtias, 2014). jika NPF rendah maka pembiayaan bermasalah yang dialami semakin kecil dan penyaluran pembiayaan akan semakin meningkat termasuk pembiayaan murabahah. Berdasarkan penelitian yang dilakukan Fahlevi (2016) dikatakan bahwa NPF berpengaruh negatif terhadap pembiayaan murabahah.

$\mathrm{H}_{4}$ : Non Performing Financing berpengaruh negatif terhadap Pembiayaan Murabahah.

\section{METODE PENELITIAN}

Penelitian ini mengunakan jenis penelitian kuantitatif dengan melakukan uji hipotesis, yaitu studi di mana peneliti berminat untuk menemukan variabel penting yang berkaitan dengan fenomena yang di teliti antara variabel independen terhadap variabel dependen.

\section{Variabel Dependen}

a. Pembiayaan Murabahah 
Pembiayaan Murabahah adalah piutang murabahah dikurangi pendapatan margin yang ditangguhkan dikurangi dengan penyisihan kerugian piutang (Nahrawi, 2017).

\section{Variabel Independen}

a. Capital Adequacy Ratio

Capital Adequacy Ratio merupakan rasio antara modal dibagi dengan aktiva tertimbang menurut resiko (Nahrawi, 2017). Jika nilai Batas wajib bank untuk menyediakan modal adalah $8 \%$.

\section{b. Dana Pihak Ketiga}

Dana Pihak Ketiga merupakan dana dalam bentuk giro ditambah deposito dan ditambah tabungan (Aziza \& Mulazid, 2017).

\section{c. Financing to Deposit Ratio}

Financing to Deposit Ratio merupakan rasio antara total kredit/ pembiayaan dibagi dengan total dana pihak ketiga (Siagian et al, 2017). Dikatakan sehat bila bank berada pada angka $85 \%$ $110 \%$.

\section{d. Non Performing Financing}

Non Performing Financing merupakan rasio antara pembiayaan yang bermasalah dengan total pembiayaan yang disalurkan oleh bank syariah (Siagian et al., 2017). Menurut Aziza \& Mulazid (2017) berdasarkan kriteria Bank Indonesia yang termasuk kategori NPF adalah kurang lancar, diragukan dan macet.

\section{Populasi dan Sampel}

Populasi dalam penelitian ini adalah Bank Umum Syariah yang sudah terdaftar di Bank Indonesia periode 2013 - 2018 .

Kriteria pengambilan sampel dalam penelitian ini adalah sebagai berikut:

1. Bank Umum Syariah yang beroperasi dari 2013 - 2018.

2. Bank Umum Syariah yang tergolong ke dalam Bank Umum Syariah Devisa dan Bank Umum Syariah Non Devisa.

3. Bank Umum Syariah yang mempublikasikan laporan tahunan (annual report) secara lengkap periode 2013 - 2018 .

4. Bank Umum Syariah yang menerbitkan laporan keuangan menggunakan mata uang rupiah selama periode 2013 2018.

\section{Metode Analisis Data}

Teknik analisis yang digunakan dalam penelitian ini meliputi statistik deskriptif, uji asumsi klasik dan uji hipotesis. Statistik deskriptif dimaksudkan untuk memberikan gambaran atau deskripsi suatu data yang dilihat dari nilai rata-rata (mean), standar deviasi, varian, maksimum, minimum, sum, range, dan sebagainya (Ghozali, 2007). Persamaan analisis regresi data panel dapat ditulis:

$$
\begin{aligned}
Y_{\text {it }}= & \beta_{0}+\beta_{1} X_{1 i t}+\beta_{2} X_{2 i t}+\beta_{3} X_{3 i t} \\
& +\varepsilon_{\text {it }}
\end{aligned}
$$

\section{HASIL DAN PEMBAHASAN}

\section{Statistik Deskriptif}

Berdasarkan hasil analisis statistic deskriptif, maka dalam tabel berikut ditampilkan 
karakteristik sampel yang digunakan.

Tabel 1

Hasil Analisis Statistik Deskriptif

\begin{tabular}{|l|r|c|c|c|c|}
\hline & Murabahah & CAR & DPK & FDR & NPF \\
\hline Mean & 15.43503 & 0.184796 & 16.24331 & 0.890665 & 0.033378 \\
\hline Median & 15.23920 & 0.163700 & 15.74738 & 0.903500 & 0.029650 \\
\hline Maximum & 17.46240 & 0.367000 & 18.28683 & 1.047500 & 0.220400 \\
\hline Minimum & 13.02426 & 0.111000 & 14.34811 & 0.718700 & 0.000000 \\
\hline Std. Dev & 1.261968 & 0.056748 & 1.096403 & 0.074401 & 0.036728 \\
\hline Skewness & -0.084630 & 1.276303 & 0.379330 & -0.265543 & 3.607282 \\
\hline Kurtosis & 1.907905 & 4.456616 & 1.752282 & 2.636379 & 17.803550 \\
\hline & & & & & \\
\hline Jarque-Bera & 2.747970 & 19.434440 & 4.797825 & 0.932114 & 610.1886 \\
\hline Probabilitity & 0.253096 & 0.0000060 & 0.090817 & 0.627472 & 0.000000 \\
\hline & & & & & \\
\hline & 833.4919 & 9.979000 & 877.1389 & 48.09590 & 1.802400 \\
\hline Sum & & & & & \\
\hline Sum Sq. Dev. & 84.405810 & 0.170679 & 63.71132 & 0.293382 & 0.071495 \\
\hline & & & & & \\
\hline Observations & 54 & 54 & 54 & 54 & 54 \\
\hline
\end{tabular}

Sumber: Output Eviews 9.0

Berdasarkan hasil analisis statistik deskriptif diatas untuk 54 sampel yang berasal dari 9 bank umum syariah dengan periode pengamatan selama 6 tahun yaitu dari tahun 2013 - 2018 dapat dijelaskan sebagai berikut:

a. Diketahui bahwa mean atau nilai rata - rata variabel Pembiayaan Murabahah pada 9 bank umum syariah yang diteliti memiliki nilai sebesar 15,43503 sedangkan Standard Deviation sebesar 1,261968. Ini menunjukkan bahwa Pembiayaan Murabahah memiliki sebaran data yang bagus.

b. Diketahui bahwa mean atau nilai rata - rata variabel Capital Adequacy Ratio pada 9 bank umum syariah yang diteliti memiliki nilai sebesar 0,184796 sedangkan Standard Deviation sebesar $\quad 0,056748$ Ini menunjukkan bahwa Capital Adequacy Ratio memiliki sebaran data yang bagus. c. Diketahui bahwa mean atau nilai rata - rata variabel Dana Pihak Ketiga pada 9 bank umum syariah yang diteliti memiliki nilai sebesar 16,24331 sedangkan Standard Deviation sebesar 1,096403. Ini menunjukkan bahwa Dana Pihak Ketiga memiliki sebaran data yang bagus.

d. Diketahui bahwa mean atau nilai rata - rata variabel Financing to Deposit Ratio pada 9 bank umum syariah yang diteliti memiliki nilai sebesar 0,890665 sedangkan Standard Deviation sebesar $\quad 0,074401$ Ini menunjukkan bahwa Financing to Deposit Ratio memiliki sebaran data yang bagus.

e. Diketahui bahwa mean atau nilai rata - rata variabel Non Performing Financing pada 9 bank umum syariah yang diteliti memiliki nilai sebesar 0,033378 sedangkan Standard Deviation sebesar 0,036728. Ini menunjukkan bahwa Non Performing Financing memiliki sebaran data yang tidak bagus.

\section{Uji Hipotesis}

\section{a. Uji F}

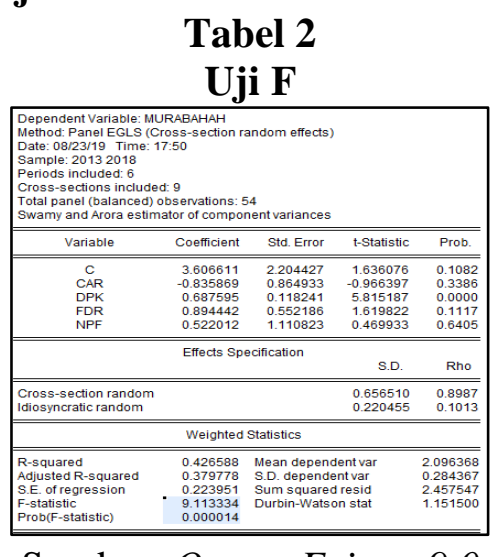

Sumber: Output Eviews 9.0

Pada output diatas menunjukkan bahwa nilai $F$ - 
Statistic sebesar 9,113334 > F

Tabel $(2,56112403)$ dan nilai Prob (F-Statistic) 0,000014 < dari 0,05 , maka dapat disimpulkan bahwa $\mathrm{Ha}$ diterima yang artinya bahwa variabel independen yang terdiri dari CAR, DPK, FDR, dan NPF layak untuk digunakan

\section{b. Uji $\quad \mathbf{R}^{2} \quad$ (Koefisien Determinasi)}

Tabel 3

$\mathbf{U j i}^{2} \mathbf{R}^{2}$ (Koefisien Determinasi)

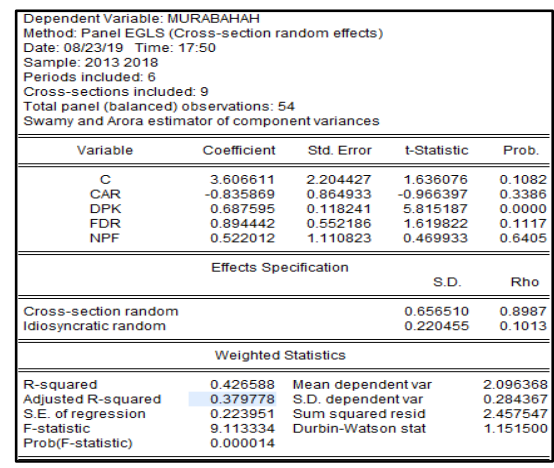

Sumber: Output Eviews 9.0

Pada tabel diatas menunjukkan bahwa nilai Adjusted $R$ Squared sebesar 0,379778, artinya bahwa variasi perubahan naik turunnya Pembiayaan Murabahah dapat dijelaskan oleh CAR, DPK, FDR, dan NPF sebesar $37,97 \%$, dan sisanya $62,03 \%$ dijelaskan oleh variabel variabel lain yang tidak diteliti oleh penelitian ini. c. Uji t

Tabel 4

Uji t

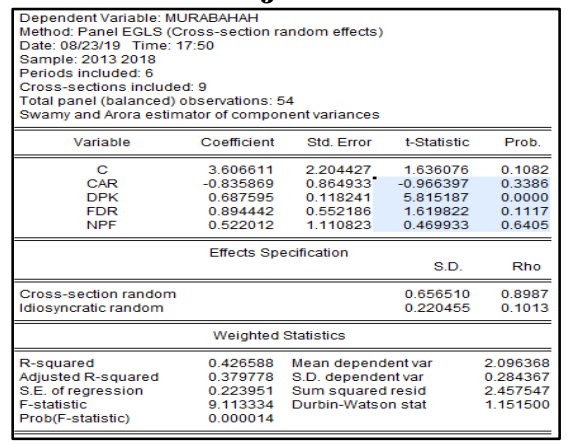

Sumber: Output Eviews 9.0

Pada tabel diatas menunjukkan bahwa:

a. Nilai t-statistic Capital Adequacy Ratio (CAR) sebesar $\quad-0,966397$, sementara $t$ Tabel dengan tingkat $\alpha=5 \%$ df $(n-k)=49$ didapat nilai t Tabel sebesar 2,009575237. Dengan demikian $t$-statistic CAR ($0,966397)<\mathrm{t}$ Tabel $(2,009575237)$ dan nilai Prob. 0,3386 > 0,05. Maka dapat disimpulan bahwa variabel Capital Adequacy Ratio dalam penelitian ini tidak berpengaruh terhadap Pembiayaan Murabahah.

b. Nilai t-statistic Dana Pihak Ketiga (DPK) sebesar 5,815187 , sementara t Tabel dengan tingkat $\alpha=5 \%$ df $(\mathrm{n}-\mathrm{k})=49$ didapat nilai $\mathrm{t}$ Tabel sebesar 2,009575237. Dengan demikian $t$-statistic DPK $(5,815187)>\mathrm{t}$ Tabel $(2,009575237)$ dan nilai Prob. 0,0000 < 0,05. Maka dapat disimpulan bahwa variabel Dana Pihak Ketiga (DPK) dalam penelitian ini berpengaruh positif 


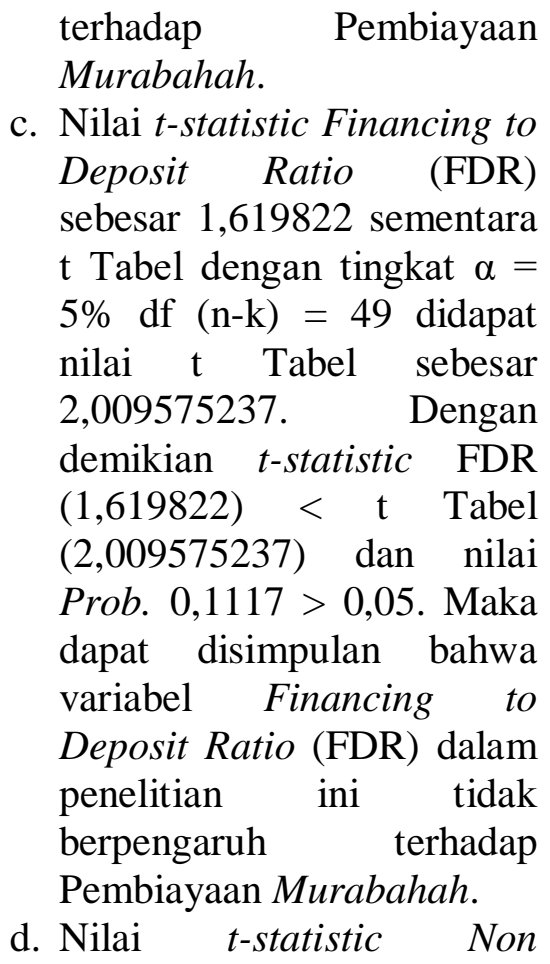

Performing Financing

(NPF) sebesar 0,469933 sementara $t$ Tabel dengan tingkat $\alpha=5 \% \mathrm{df}(\mathrm{n}-\mathrm{k})=49$ didapat nilai $\mathrm{t}$ Tabel sebesar 2,009575237. Dengan demikian t-statistic NPF $(0,469933)<\mathrm{t}$ Tabel $(2,009575237)$ dan nilai Prob. 0,6405 > 0,05. Maka dapat disimpulan bahwa variabel Non Performing Financing (NPF) dalam penelitian ini tidak berpengaruh terhadap Pembiayaan Murabahah.

\section{d. Persamaan Model Regresi Data Panel}

Berdasarkan Output Eviews 9.0, model Regresi Data Panel dapat dirumuskan sebagai berikut:

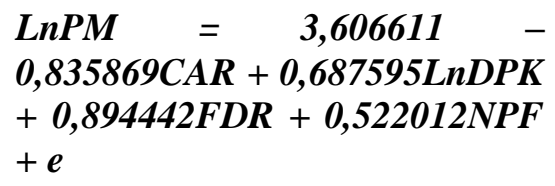

Hasil yang didapat
menjelaskan bahwa Dana
Pihak Ketiga berpengaruh
positif terhadap Pembiayaan
Murabahah, hal ini didasarkan
pada nilai probabilitas variabel
Dana Pihak Ketiga sebesar
0,0000 , dimana nilai tersebut <
0,05 .

\section{KESIMPULAN}

Berdasarkan hasil pengujian yang telah dilakukan, dapat disimpulkan beberapa hal, yaitu:

1. Nilai t-statistic CAR $(-0,966397)$ $<$ t Tabel $(2,009575237)$ dan nilai Prob. 0,3386 > 0,05. Maka dapat disimpulan bahwa variabel Capital Adequacy Ratio dalam penelitian ini tidak berpengaruh terhadap Pembiayaan Murabahah.

2. Nilai $t$-statistic DPK $(5,815187)>$ t Tabel $(2,009575237)$ dan nilai Prob. 0,0000 > 0,05. Maka dapat disimpulan bahwa variabel Dana Pihak Ketiga (DPK) dalam penelitian ini berpengaruh positif terhadap Pembiayaan Murabahah.

3. Nilai $t$-statistic FDR $(1,619822)<$ t Tabel $(2,009575237)$ dan nilai Prob. 0,1117 > 0,05. Maka dapat disimpulan bahwa variabel Financing to Deposit Ratio (FDR) dalam penelitian ini tidak berpengaruh terhadap Pembiayaan Murabahah.

4. Nilai t-statistic NPF $(0,469933)<$ $\mathrm{t}$ Tabel $(2,009575237)$ dan nilai Prob. 0,6405 > 0,05. Maka dapat disimpulkan bahwa variabel Non Performing Financing (NPF) dalam penelitian ini tidak berpengaruh terhadap Pembiayaan Murabahah 


\section{DAFTAR PUSTAKA}

Afrida, Y. (2016).Analisis Pembiayaan Murabahah di Perbankan Syariah. JEBI (Jurnal Ekonomi Dan Bisnis Islam), 1(2), 155-166.

Ahmad Misbahul. (2016). Pengaruh FDR, BOPO, NPF dan Inflasi Terhadap Pembiayaan Murabahah Perbankan Syariah Tahun 2010 - 2015.

Ali, H., \& Miftahurrohman, M. (2016). Determinan yang Mempengaruhi Pembiayaan Murabahah Pada Perbankan Syariah di Indonesia. ESENSI, 6(1), 31-44.

Antonio, M. Syafi'i. (2001). Bank Syariah dari Teori ke Praktik. Jakarta : Gema Insani.

Aziza, R. V. S., \& Mulazid, A. S. (2017). Analisis Pengaruh Dana Pihak Ketiga , Non Performing Financing , Capital Adequacy Ratio , Modal Sendiri dan Marjin Keuntungan Terhadap Pembiayaan Murabahah. Jurnal Ekonomi Dan Bisnis Islam, 2(1), 1-15.

Azmi, F. (2015). Faktor Internal dan Eksternal Yang Mempengaruhi Pembiayaan Murabahah Pada Perbankan Syariah di Indonesia. Graduasi, 34(1), 53-70.

Bank Indonesia. (1998). UndangUndang Nomor 10 Tahun 1998 Tentang Perbankan. UndangUndang No. 10 Tahun 1998 Tentang Perbankan.

Fahlevi, R. (2016). Analisis Pengaruh Inflasi, Sertifikat Bank Indonesia Syariah (SBIS), Non Performing Financing (NPF) dan Dana Pihak Ketiga
(DPK) terhadap Pembiayaan Murabahah pada Bank Syariah di Indonesia. 7(1), 71-82.

Fauzan, M. (2018). Pengaruh Dana Pihak Ketiga Dan Modal Sendiri Terhadap Pembiayaan Murabahah. Jurnal Sekuritas Saham, Ekonomi, Keuangan Dan Investasi, 1(3), 84-106.

Fatwa - Fatwa Dewan Syariah Nasional (DSN) - MUI. 2002.

Jurnal Ekonomi Syariah. 2016.

Mizan. (2017). DPK, CAR, NPF, DER, dan ROA Terhadap Pembiayaan Murabahah Pada Bank Umum Syariah. Balance, $X I V(1), 72-83$.

Muda, I., \& Afifah, N. (2018). Analysis of Non Performing Financing (NPF), Financing to Deposit Ratio (FDR), Third Party Funds And Debt to Equity Ratio (DER) Murabahah of Funding in Indonesia. Talenta Conference Series: Local Wisdom, Social, and Arts (LWSA), 1(1), 120-127.

Nahrawi, A. A. (2017). Pengaruh Capital Adequacy Ratio (CAR), Return On Assets (ROA) dan Non Performing Financing (NPF) Terhadap Pembiayaan Murabahah BNI Syariah. Perisai: Islamic Banking and Finance Journal, 1(2), 141179.

Otoritas Jasa Keuangan. 2014. Statistik Perbankan Syariah Desember 2014. Jakarta: Otoritas Jasa Keuangan.

Otoritas Jasa Keuangan. 2016. Statistik Perbankan Syariah 
Desember 2016. Jakarta: Otoritas Jasa Keuangan

Otoritas Jasa Keuangan. 2017. Statistik Perbankan Syariah Desember 2017. Jakarta: Otoritas Jasa Keuangan.

Refinaldy, A, Septarina Prita Dania Sofianti, dan Yosefa S. (2018). Pengaruh Tingkat Risiko Pembiayaan Musyarakah dan Pembiayaan Mudharabah Terhadap Tingkat Profitabilitas Bank Syariah. Jurnal RELASI STIE Mandala Jember, 4(1), 126-139. 